\title{
RAGAM PROFESIONALISME GURU BIMBINGAN DAN KONSELING ZAMAN NOW
}

\author{
M Adi Putra AP \\ SMK Negeri 2 Lamongan/e-mail: adiputra.smkn2@gmail.com \\ Nurida Shofaria \\ SMK Negeri Sarirejo/e-mail: nuridashofaria01@gmail.com
}

\begin{abstract}
Abstrak
Guru Bimbingan Konseling/Konselor di zaman now harus mempunyai dasar keilmuan pendidikan yang kuat, karena Konselor sebagai salah satu jenis tenaga kependidikan dalam Undang-Undang Republik Indonesia Nomor 20 Tahun 2003. Sejalan dengan pengakuan konselor kebijakan pemerintah dalam pengembangan kualitas guru Bimbingan dan Konseling. Kebijakan sertifikasi guru diharapkan mampu meningkatkan kualitas keprofesionalan guru Bimbingan Konseling/Konselor. Namun, sertifikasi guru tidak berdampak signifikan terhadap peningkatan profesionalitas guru bimbingan dan konseling, masih banyak Guru Bimbingan Konseling/Konselor nilai UKG nya rendah, masih banyak Guru Bimbingan Konseling/Konselor mutu kinerjanya rendah dan minimnya kontribusi karya ilmiah yang di hasilkan guru Bimbingan Konseling/Konselor, oleh sebab itu perlu ragam bentuk peningkatan profesonal Guru Bimbingan dan Konseling sehingga menambah pilihan metode Guru Bimbingan Konseling/Konselor dalam mengembangkan keprofesionalan Skills. Dalam mengembangkan keprofesionalan Guru Bimbingan Konseling/Konselor ada beberapa metode, metode dalam bentuk pendidikan dan pelatihan (diklat) dan bukan diklat, dan untuk mewujudkan guru yang benar-benar profesional dan kompeten tidak cukup dengan mengikuti program sertifikasi PLPG/PPG, pemerintah harus memiliki program lanjutan setelah guru Bimbingan konseling/Konselor memiliki sertifikat profesional untuk mempertahankan dan meng upgread keilmuan sesuai perkembangan zaman, ada dimensi yang harus dipenuhi agar profesionalismenya tetap terjaga, menjamin dan selalu meningkat sesuai dengan kebutuhan serta tuntutan yang berkembang antara lain dengan Pengembangan Keprofesian Berkelanjutan (Continuing Professionality Development). Guru Bimbingan Konseling/konselor terfasilitasi dan rutin melakukan Pengembangan Keprofesian Berkelanjutan pastinya akan menunjukkan hasil sangat signifikan perkembangan Skills Guru Bimbingan Konseling/Konselor sehingga menambah wawasan, keterampilan dan kompetensi dalam era zaman now.
\end{abstract}

Kata kunci: professional, keprofesian berkelanjutan, Guru BK/Konselor

\begin{abstract}
Teacher Guidance and Counseling in the present day must have a strong foundation of educational science, because the Counselor is one of the types of education personnel in the Law of the Republic of Indonesia Number 20 of 2003. In line with the recognition of government policy counselors in developing the quality of teacher Guidance and Counseling. Teacher certification policy is expected to be able to improve the quality of teacher professionalism Counseling Guidance / Counselor. However, teacher certification did not have a significant impact on improving the professionalism of teacher guidance and counseling, there are still many teachers who have low UKG Counseling / Counselor scores, there are still many Teachers Counseling Guidance / low quality quality counselors and the lack of scientific work contributions generated by teachers Counseling Guidance / Counselors Therefore, it is necessary to have various forms of professional improvement in Guidance and Counseling Teachers so as to increase the choice of Counseling / Counselor Guidance methods in developing Skills professionalism. In developing the professionalism of the Counseling / Counselor Guidance there are several methods, methods in the form of education and training and not education and training, and to realize a truly professional and competent teacher is not enough to follow the PLPG / PPG certification program, the government must have a program continued after the teacher Counseling / Counselor Guidance has a professional certificate to maintain and uplift knowledge according to the times, there are dimensions that must be fulfilled so that the professionalism is maintained, guarantees and always increases in accordance with the needs and demands that develop, among others, with Continuing Professionality Development). Facilitated Counseling / Counseling Teachers and routinely carrying out Continuous Professional Development will certainly show very significant results in the development of Counseling / Counseling Teacher Skills so as to add insight, skills and competencies in today's era.
\end{abstract}

Keywords: professional, continuous professionalism, counselor / counselor 


\section{PENDAHULUAN}

Pada zaman now, termasuk Indonesia, profesi guru memiliki posisi strategis karena penyandangnya mempunyai tugas sejati bagi proses kemanusiaan, pemanusiaan, pencerdasan, pembudayaan, dan pembangun karakter bangsa. Makna posisi strategis sekaligus meniscayakan pengakuan posisi guru sebagai profesi. Undangundang RI Nomor 20 Tahun 2003 tentang Sistem Pendidikan Nasional, Undang-undang RI Nomor 14 Tahun 2005 tentang Guru dan Dosen, Peraturan Pemerintah RI Nomor 19 Tahun 2005 tentang Standar Nasional Pendidikan, dan Peraturan Pemerintah RI Nomor 74 Tahun 2008 Tentang Guru menyatakan guru adalah pendidik profesional. Guru yang dimaksud meliputi guru kelas, guru mata pelajaran, guru bimbingan konseling atau konselor, dan guru pembimbing teknologi informasi dan komunikasi (TIK) dan keterampilan komputer dan pengelolaan informasi (KKPI). Guru profesional dipersyaratkan memiliki kualifikasi akademik yang relevan dengan mata pelajaran yang diampu dan menguasai kompetensi sebagaimana dituntut oleh Undang-undang Guru dan Dosen. Pengakuan guru sebagai pendidik profesional dibuktikan dengan sertifikat pendidik yang diperoleh melalui suatu proses sistematik yang disebut sertifikasi.

Ketika Guru Bimbingan Konseling/ konselor telah ditetapkan sebagai pendidik profesional atas dasar ketentuan ini maka terdapat berbagai konsekuensi yang menyertainya mulai dari persyaratan-persyaratan kompetensi yang harus dipenuhi terutama yang berkaitan dengan kualifikasi pendidikan minimal kepemilikan ijazah sarjana satu (S1) dalam bidang bimbingan dan Konseling dari perguruan tinggi terakreditasi oleh lembaga akreditasi yang sah. Pengakuan legalistik atas penguasaan kompetensi yang dipersyaratkan oleh lembaga pendidikan tenaga kependidikan (LPTK) atau institusi berwenang yang ditunjuk oleh pemerintah.

Pemenuhan kualifikasi penguasaan
kompetensi kinerja guru Bimbingan
Konseling/Konselor yang baik berupa enabling
competencies (kompetensi prasyarat) maupun
performance competencies (kompetensi tampilan
kinerja) dilakukan melalui pendidikan profesi dalam
kurun waktu tertentu yang diakhiri dengan uji
kompetensi. Jika guru Bimbingan
Konseling/Konselor tersebut berhasil mendapatkan
nilai uji kompetensi di atas nilai batas minimal yang
bersangkutan akan memperoleh sertifikat profesi
sebagai penanda bahwa pemegangnya telah lulus uji
kompetensi dan disebut guru professional. Lebih
lanjut setelah memenuhi ketentuan tersebut, ketika
bekerja yang bersangkutan juga harus pula

mengikuti alur prosedur atau standar operasional prosedur (SOP) sebagai dasar pedoman dalam bekerjanya. Ia harus bekerja berdasar pada teori, paradigma, pendekatan serta teknik yang telah ada dan relative baku yang tertera pada buku panduan operasional penyelenggaraan bimbingan konseling (POP BK).

Tahapan dalam pelaksanaan program layanan BK mengikuti cara tertentu seperti melalui tahap planning, designing, implementing, evaluating, and enhancing (Gysbers and Henderson. 2006). Oleh sebab itu bukan berarti guru Bimbingan Konseling/Konselor harus terpaku dengan ketentuan secara rigid dengan tanpa memiliki kebebasan melakukan inovasi. Justru seiring dengan aktifitas pengalaman di sekolahnya masing-masing diharapkan mampu membuat kajian, penelitian tindakan bimbingan konseling, diskusi dengan sejawat di musyawarah guru bimbingan konseling (MGBK) sehingga dapat tercipta teknik-teknik baru dalam layanan bimbingan konseling.

Guru Bimbingan Konseling/Konselor adalah sebuah profesi, disiplin keilmuan dan peran yang dilakukan oleh Guru Bimbingan Konseling/ Konselor kepada peserta didik merupakan layanan profesi. Guru Bimbingan Konseling/Konselor merupakan pekerjaan atau karier yang bersifat pelayanan memiliki skills khusus dengan tingkat ketepatan yang tinggi untuk membantu peserta didik dalam bidang pribadi, belajar, sosial dan karier . guru Bimbingan Konseling/Konselor sebagai profesi yang bersifat memberikan layanan peserta didik dengan landasan ilmu dan teknologi serta wilayah praktik yang jelas dan dapat dibedakan dengan profesi-profesi lain yang bersifat membantu. Guru Bimbingan Konseling/konselor merupakan profesi yang dinamis, selalu berkembang dan menyenang-kan, yang selalu berhubungan dengan perkembangan karakteristik peserta didik dan kemungkinan dalam cara yang intensif, personal dan perhatian. Guru Bimbingan Konseling/Konselor merupakan profesi yang diperuntukan bagi setiap perkembangan peserta didik dalam upaya pencegahan, pengembangan, eksplorasi, pemberdayaan, perubahan, kemandirian dan remediasi dalam kehidupan sehari-hari yang semakin kompleks dan penuh tantangan.

Guru Bimbingan Konseling/Konselor dalam melaksanakan konseling berusaha sebaik mungkin untuk mendengarkan, memahami, menganalisa dan kemudian bekerja sama dengan klien/peserta didik untuk menemukan solusi serta cara terbaik dalam membantu memenuhi kebutuhan, memenuhi harapan, mengoptimalkan kemampuan, mengembangkan diri, mencapai kemandirian dan memecahkan masalah peserta didik. Guru Bimbingan Konseling/Konselor melalui aktifitas 
konseling membantu individu untuk mengubah kesenjangan antara harapan dengan kenyatan dan memiliki perbedaan nyata antara sebelum dan sesudah konseling berkaitan dengan pemecahan masalah, pemenuhan kebutuhan, harapan, pengembangan diri, pencapaian kemandirian dalam kehidupannya. Hasil konseling akan sangat bergantung pada diri seseorang yang dibantu untuk berubah, sebab perubahan perilaku dalam konseling sangat tergantung pada kemauan, kesiapan dan kemampuan orang yang dilayani melalui konseling oleh konselor (Mungin EW, 2016).

Guru Bimbingan Konseling/konselor merupakan profesi bantuan (helping profession) adalah konsep yang melandasi peran dan fungsi konselor di masyarakat saat ini. Yang dimaksud Profesi guru Bimbingan Konseling/konselor sebagai profesi bantuan adalah profesi yang anggotaanggotanya dilatih khusus dan memiliki lisensi skills atau sertifikat untuk melakukan sebuah layanan bimbingan konseling dan dibutuhkan oleh peserta didik maupun masyarakat, yaitu layanan konseling. Seperti halnya, konseling keluarga, konseling karir, dsb. Konselor adalah tenaga spesialis yang terlatih dan terakreditasi dalam bidang konseling. Konselor adalah pendidik profesional yang berkualifikasi akademik minimal Sarjana Pendidikan (S-1) dan telah lulus Pendidikan Profesi Guru Bimbingan dan Konseling/ Konselor.

Kita harus mengakui jika ikatan disipliner terkuat bagi profesi guru bimbingan konseling/konselor adalah dengan bidang psikologi, namun kita juga harus mengakui kontribusi penting ilmu-ilmu lain bagi profesi konseling, sebagai halnya, ilmu sosiologi memberi kontribusi bagi pengertian tentang kelompok-kelompok masyarakat dan pengaruhnya terhadap pranata dan perubahan sosial. Ilmu antropologi menyediakan ragam wawasan bagi para konselor tentang pemahaman budaya-budaya atau kelompok manusia, yang pada gilirannya menyediakan norma bagi cara bersikap dan memandang anggota-anggotanya. ilmu Biologi membantu konselor dalam memahami organisme manusia dsb. Sedangkan profesi kesehatan membuat kita sadar pentingnya kesejahteraan hidup dan pencegahan dari penyakit, penyimpangan dan gangguan baik mental maupun fisik (Gibson \& Mitchel, 2011: 29).

Guru Bimbingan Konseling/Konselor di Indonesia harus memiliki kemampuan dasar keilmuan pendidikan yang kuat, karena Konselor sebagai salah satu jenis tenaga kependidikan dalam Undang-Undang Republik Indonesia Nomor 20 Tahun 2003 tentang Sistem Pendidikan Nasional. Pada Bab I Pasal 1 angka 6 dinyatakan bahwa - pendidik adalah tenaga kependidikan yang berkualifikasi sebagai guru, dosen, konselor, pamong belajar, widyaiswara, tutor, instruktur, fasilitator, dan sebutan lain yang sesuai dengan kekhususannya, serta berpartisipasi dalam penyelenggaraan pendidikan. Pendidikan membantu profesi konselor memahami proses pemberdayaan dan pembudayaan manusia yang sedang berkembang menuju kepribadian mandiri untuk dapat membangun dirinya sendiri dan masyarakat. Melalui pendidikan konselor membantu manusia/konseli berkembang ke arah bagaimana dia harus menjadi bermafaat di sekitar dan berada, karena pendidikan harus bertolak dari pemahaman tentang hakikat manusia. Pendidikan berupaya memahami manusia dalam segala hal aktualisasinya, kemungkinannya, dan pemikirannya, bahkan memahami perubahan yang dapat diharapkan terjadi pada diri manusia.

Sejalan dengan pengakuan profesi konselor tersebut, pemerintah membuat kebijakan dalam pengembangan kualitas guru Bimbingan dan Konseling. Kebijakan alur program sertifikasi guru yang sudah berganti dari sistem portofolio, PLPG dan PPG diharapkan mampu meningkatkan kualitas pendidikan di negeri ini. Namun hasil penelitian Caraka (2010) Sertifikasi guru belum berdampak signifikan terhadap peningkatan profesionalitas guru bimbingan dan konseling dalam memberikan layanan, masih belum ada perubahan yang signifikan peningkatan profesionalisasi guru bimbingan konseling/ Konselor antara yang telah mengikuti rangkaian sistem uji sertifikasi dengan yang belum melakukan uji sertifikasi. masih banyak Guru Bimbingan Konseling/Konselor yang telah sertifikasi nilai UKG nya rendah, masih banyak Guru Bimbingan Konseling/Konselor yang telah sertifikasi mutu kinerjanya rendah.

Keprofesionalitas seorang Guru Bimbingan Konseling/konselor harus tetap terjaga, bahkan keprofesionalan guru Bimbingan Konseling/ Konselor harus selalu meningkat mengikuti perkembangan zaman. Jika tidak, maka yang terjadi akan sebaliknya sangat berisiko merugikan peserta didik/konseli yang mendapatkan layanan darinya.

Guru Bimbingan Konseling/Konselor harus berusaha dengan berbagai macam cara agar keprofesionalan yang dimiliki tetap standar tidak menurun, syukur selalu meningkat sesuai perkembangan zaman. Guru Bimbingan Konseling/Konselor harus pandai mencari metode atau teknik untuk pengembangan diri menuju Guru Bimbingan Konseling/Konselor Profesional. Karena itulah maka adanya upaya untuk pengembangan professional Guru BK menjadi sebuah keniscayaan. Diberlakukannya UKG Online secara periodik bagi profesi guru bimbingan konseling/konselor merupakan ide bagus yang 
pantas dipertimbangkan untuk menjaga keprofesionalan guru bimbingan konseling/ Konselor tetap terjaga. Adanya UKG online ini akan menjadi motivasi agar setiap Guru bimbingan konseling/Konselor selalu menjaga keilmuannya, keterampilannya dan keahliannya dalam hal konseling bahkan dimungkinkan adanya motivasi yang lebih tinggi lagi untuk lebih meningkatkan keprofesionalitasnya untuk mewujudkan Guru Bimbingan Konseling/Konselor yang benar-benar profesional dan kompeten tidak hanya cukup mengejar lulus sertifikasi dan menikmati segala fasilitas/tunjangan yang diberikan. Namun, ada aturan yang harus dipenuhi agar profesionalismenya tetap terjaga, menjamin dan selalu meningkat sesuai dengan kebutuhan peserta didik serta tuntutan pengembangan Profesionalisme Guru Bimbingan Konseling/ Konselor zaman now.

\section{PROFESIONALISME GURU BIMBINGAN KONSELING/KONSELOR}

Kondisi rill keprofesionalan guru bimbingan konseling/Konselor saat ini cukup rendah, terbukti dari hasil nilai UKG Online perlu peninjauan kembali dan merumuskan langkah strategi untuk memberikan stimulus model pendidikan latihan maupun metode untuk menjaga dan meningkatkan keprofesionalan guru bimbingan konseling/konselor pada saat ini. Berdasarkan Peraturan Menteri pendidikan dan Kebudayaan Republik Indonesia Nomor 16 tahun 2007 tentang standar kualifikasi Akademik dan Kompetensi guru, ada empat kompetensi yang harus dimiliki oleh tenaga guru yakni kompetensi pedagogik, kepribadian, profesional dan sosial.

Program peningkatan kompetensi Guru bimbingan konseling/Konselor sudah dilakukan oleh kemdikbud melalui Dirjen GTK dengan berbagai program peningkatan kompetensi. Searah dengan program Kemendikbud, guru Bimbingan Konseling/Konselor diharapkan meningkat kompetensinya dan mampu bekerja secara profesional. Pengertian profesional adalah istilah bagi seseorang yang menawarkan jasa atau layanan sesuai dengan aturan dalam bidang yang dijalaninya dan mendapatkan gaji sebagai upah jasanya.

Guru bimbingan merupakan pemberi jasa layanan kepada peserta didik sehingga dituntut untuk bekerja secara profesional sehingga ada timbal balik dari tunjangan profesi. Salah satu kriteria pekerjaan profesional itu ditulis oleh Abraham Flexner tahun 1915 yang melihat kriteria profesi dalam enam karakteristik, yaitu: keintelektualan, kompetensi profesional yang dipelajari, objek praktik spesifik, komunikasi, motivasi altruistik, dan organisasi profesi. a. Keintelektualan. Pekerjaan profesional merupakan layanan yang lebih berorientasi mental daripada manual (kegiatan yang mengutamakan keterampilan fisik); lebih memerlukan proses berpikir daripada kegiatan rutin. Melalui proses berpikir tersebut, pelayanan profesional merupakan hasil pertimbangan yang matang, berdasarkan kaidah-kaidah keilmuan yang dapat dipertanggung-jawabkan secara ilmiah.

b. Kompetensi profesional yang dipelajari. Pekerjaan profesional didasarkan pada kompetensi yang baik, tidak diperoleh begitu saja. misalnya melalui mimpi, melalui wangsit atau menyendiri sekian lama, atau melalui penyajian larung sesaji ke laut. Seorang yang profesional harus dengan sungguh-sungguh, serta mencurahkan segenap pikiran dan usaha, untuk mempelajari materi keilmuan, pendekatan, metode dan teknik, serta nilai berkenaan dengan pelayanan yang dimaksud.

c. Objek praktik spesifik. Pekerjaan suatu profesi tertentu terarah kepada objek praktik spesifik yakni Konseli. berdasarkan peraturan yang berlaku, guru bimbingan konseling/konselor konselor menangani peserta didik normal yang mengalami masalah dalam kehidupan seharihari yang dapat mengimbas kepada pola kehidupan yang lebih luas dan masa depannya. Tidak lain adalah pelayanan berkenaan dengan penyelenggaraan proses pembelajaran terhadap peserta didik dalam bidang pelayanan yang menjadi kekhususan pekerjaan guru bimbingan konseling/ konselor Demikianlah, objek praktik spesifik guru bimbingan konseling/konselor harus dibedakan dari tangan guru mata pelajaran dan jenis petugas pendidik lainnya, kendatipun sama-sama profesi dalam bidang pendidikan.

d. Komunikasi. Seluruh proses pelayanan profesional, tidak lepas dari komunikasi. meliputi objek praktik spesifik profesinya, keilmuan dan teknologinya, kompetensi dari dinamika operasionalnya, aspek hukum dan sosialnya, termasuk kode etik dan aturan kredensialisasi, serta imbalan yang terkait dengan pelaksanaan pelayanannya, semuanya dapat dikomunikasikan kepada siapapun yang berkepentingan,.

e. Motivasi altruistik. Motivasi kerja seorang guru bimbingan konseling/Konselor profesional bukanlah berorientasi kepada kepentingan dan keuntungan pribadi, namun untuk kepentingan, keberhasasilan, dan kebahagiaan sasaran layanan yakni peserta 
didik/konseli, serta kemaslahatan kehidupan masyarakat pada umumnya. Motivasi altruistik diwujudkan melalui peningkatan keintelektualan, kompetensi dan komunikasi dalam menangani objek praktik spesifik profesi.

f. Organisasi profesi. Tenaga profesional dalam profesi yang sama membentuk suatu wadah perkumpulan atau disebut organisasi profesi untuk mengawal pelaksanaan tugastugas profesional mereka, seperti halnya musyawarah guru bimbingan konseling (MGBK), Asosiasi Bimbingan Konseling Indonesia (ABKIN), Ikatan Bimbingan Konseling Sekolah (IBKS) dsb.

Memperhatikan karakteristik yang menjadi tuntutan suatu profesi, dapatlah dipahami sepenuhnya bahwa tenaga profesional perlu dipersiapkan di lembaga pendidik tenaga kependidikan (LPTK), mulai dari pendidikan program sarjananya sampai dengan objek praktik program pendidikan profesinya. Aspek-aspek keintelektualan/ keilmuan, kompetensi dan teknologi operasional, kode etik, dan aspek-aspek sosialnya seluruhnya dipelajari melalui Program Sarjana Pendidikan dan Pendidikan Profesi.

Profesi pada hakikatnya merupakan suatu pekerjaan tertentu yang menununtut persyaratan khusus sehingga dapat meyakinkan dan mendapat kepercayaan pihak yang memerlukannya (Saud, 2011:8). Dengan demikian, profesi konselor merupakan sebuah pekerjaan di bidang pendidikan yang memiliki persyaratan khusus dan istimewa yang telah ditetapkan sebagaimana mestinya sehingga meyakinkan dan memperoleh kepercayaan dari pihak yang memerlukannya dalam hal ini peserta didik yaitu konseli/klien.

Sebagai profesi, Guru Bimbingan Konseling/ Konselor juga memiliki syarat atau karakeristik sebagai suatu profesi. Karakteristiknya antara lain sebagai berikut:

\section{a. Kepercayaan publik (public trust)}

Adanya suatu profesi muncul dari kepercayaan publik (public trust). Begitu pula dengan guru Bimbingan dan Konseling/konselor profesional, kepercayaan publik akan menentukan definisi dari profesi guru bimbingan konseling/konselor itu sendiri dan sangat memungkinkan guru bimbingan konseling/ konselor untuk berfungsi dalam cara-cara yang profesional. Setiap saat penilian publik terhadap profesi dapat berubah-ubah dikarenakan perilaku tidak etis, tidak profesional atau kurang bertanggungjawab dari para anggotanya. Seorang guru bimibngan konseling/ konselor profesional mesti menaruh kepedulian, empati khusus terhadap konseli, karena konseli amat rawan untuk dimanipulasi dan dieksploitasi dalam hal ini kepentingan peserta didik.. Seorang guru bimingan konseling/konselor harus benar-benar mampu berkomitmen untuk memelihara pentingnya tanggung jawab melindungi kepercayaan konseli (public trust).

\section{b. Kode Etik}

Kode etik adalah pedoman bertindak, sikap, tingkah laku dan perbuatan dalam melaksanakan tugas di kehidupan sehari-hari. Kode etik profesi merupakan aturan jelas yang harus diindahkan setiap anggota dalam melakukan/melaksanakan tugas profesinya dalam kehidupannya di masyarakat.

Sejalan dengan adanya kepercayaan publik, maka etika sebuah profesi menjadi mutlak keberadaannya agar tetap mendapat kepercayaan publik. Asosiasi Bimbingan dan Konseling Indonesia (ABKIN) telah mengatur dan membuat aturan yang jelas untuk anggotanya, ini juga merupakan salah satu bukti sebagai aktualisasi organisasi profesi guru Bimbingan dan Konseling/konselor (ABKIN) agar diakui sebagai organisasi kode etik dan berbadan hukum.

\section{c. Kualifikasi dan Standar Kompetensi}

Guru bimbingan konseling/konselor dituntut memiliki kualifikasi akademik dan standar kompetensi. Standar kompetensi merupakan sebuah kontinum perkembangan mulai dari proses kesadaran, akomodasi serta tindakan nyata sebagai wujud kinerja. Standar kompetensi konselor menurut Kartadinata (2010:189) bersumber pada penguasaan konsep, penghayatan, perwujudan nilai, penampilan yang bersifat membantu, dan unjuk kerja profesional yang akuntabel.

Lebih diperjelas dan telah diatur dalam Peraturan Menteri Pendidikan Nasional Nomor 27 Tahun 2008 tentang Standar Kualifikasi Akademik dan Kompetensi Konselor. Pada pasal 1 ayat (1) menyebutkan bahwa - Untuk dapat diangkat sebagai konselor, seseorang wajib memenuhi standar kualifikasi akademik dan kompetensi konselor yang berlaku secara nasional. Kualifikasi akademik konselor dalam satuan pendidikan pada jalur pendidikan formal dan nonformal adalah: (1) Sarjana pendidikan (S-1) dalam bidang Bimbingan dan Konseling. (2) Berpendidikan profesi konselor. 
Bentuk utuh kompetensi guru bimbingan konseling/konselor mencakup kompetensi akademik dan profesional sebagai satu keutuhan. Kompetensi akademik merupakan landasan ilmiah dari kiat pelaksanaan pelayanan profesional bimbingan dan konseling. Kompetensi akademik merupakan landasan utama bagi pengembangan kompetensi profesional, yang meliputi: (1) memahami secara mendalam persoalan konseli yang dilayani, (2) menguasai landasan dan kerangka teoretik bimbingan dan konseling, (3)menyelenggarakan layanan bimbingan dan konseling yang memandirikan peserta didik, dan (4) mengembangkan pribadi dan profesionalitas konselor secara berkelanjutan.

\section{d. Kurikulum Pendidikan Profesi}

Kurikulum pendidkan profesi diharapkan berorientasi pada nilai-nilai praktikum yang berlapis, dimungkinan menggunakan multi entry-exit, dengan perbandingan antara teori dengan praktek 25: 75. Kegiatan praktikum konseling meliputi praktek konseling individu, konseling kelompok, bimbingan kelompok, konseling karir, asesmen dan instrumentasi bimbingan dan konseling serta pengembangan dan pengelolaan program Setting tempat kegiatan praktikum mencakup lingkungan keluarga, sekolah, masyarakat dan industri (Kartadinata, 2010: 195)

\section{PRINSIP-PRINSIP PENGEMBANGAN PROFESIOANLISME GURU BIMBINGAN KONSELING/KONSELOR}

Guru bimbingan konseling/konselor diharapkan mampu bekerja meberikan layanan secara profesional kepada peserta didik/Konseli. Prinsip ini penting untuk diperhatikan agar pengembangan yang dilakukan untuk meningkatkan profesionalitas Guru Bimbingan Konseling/Konselor dapat mencapai target dan bisa mencapai hasil yang optimal, memiliki kemanfaatn bagi peningkatan layanan bimbingan konseling kepada peserta didik/konseli. Terdapat sejumlah prinsip yang harus dipedomani dalam peningkatan keprofesionalan guru bimbingan konseling/Konselor ini, antara lain: (1) berkeadilan, (2) terbuka, (3) ilmiah, (4) komprehensif, (5) relevan, (6) memandirikan, (7) berkelanjutan, serta (8) efektif dan efisien (Danim dan Khairil. 2010; Widada. 2013).

Berkeadilan, hendaknya pelayanan konseling diberikan kepada siapapun tanpa ada pilih kasih dan diskriminasi. Setiap guru bimbingan konseling/konselor memiliki kesempatan yang sama, berhak memperoleh pengembangan untuk meningkatkan keprofesionalan hingga ke level tertinggi sesuai dengan yang diinginkan, sama-sama mendapatkan motivasi yang tinggi dan kesempatan yang mereka miliki.

Terbuka, kesempatan yang luas diberikan untuk meningkatkan keprofesionalan bagi semua Guru bimbingan konseling/konselor dengan memberikan akses informasi, pendidikan seluasluasnya. Dengan prinsip ini mereka memilih, dan mendapatkan kesempatan yang sama untuk pengembangan sesuai dengan kebutuhan yang mereka butuhkan guna keberhasilan dalam menjalankan tugas konselornya.

Ilmiah, guru bimbingan konseling/konselor melakukan pengembangan hendaknya berdasar pada kaidah keilmuan. Ini berarti pengembangan yang ia lakukan harus dapat dipertanggung jawabkan dari segi teori, metode maupun tekniknya secara keilmuan konselor.

Komprehensif, kompetensi guru bimbingan konseling/konselor hendaknya selalu mengalami peningkatan keahlian juga meliputi seluruh kompetensi yang telah ditetapkan pada seorang Guru bimbingan konseling/konselor. Artinya kompetensi yang dmiliki harus dikembangkan meliputi kompetensi pedagogik, kompetensi professional kompetensi sosial, dan kompetensi kepribadian. Dalam upaya pengembangan tidak boleh hanya sebagian kompetensi saja. Hal ini menjadi acuan seorang guru bimbingan konseling/konselor akan penekanan karena keprofesionalan seseorang itu terbentuk jika keseluruhan kompetensi itu dikuasai dengan sempurna.

Relevan, setiap layanan yang ia berikan hendaknya sesuai materi maupun kegiatan dalam pengembangan harus ada kaitannya dengan bimbingan dan konseling. Jika pengembangan itu berupa hasil penelitian, maka hasil penelitian tersebut harus ada hubungannya dengan bimbingan dan konseling. Apabila pengembangan dilakukan dengan menempuh pendidikan lanjut, maka pendidikan lanjutannya harusnya linier sesuai bidang bimbingan dan konseling.

Memandirikan, melalui pengembangan itu guru bimbingan konseling/konselor dapat memiliki keprofesionalan yang lebih tinggi dan semakin profesional dan trampil dalam memberikan layanan konseling kepada peserta didik/konseli. Kemandirian juga tercermin dalam kesadaran yang muncul dalam diri guru bimbingan konseling/konselor untuk selalu mengembangkan diri secara terus menerus agar dapat memberikan pelayanan terbaik bagi peserta didiknya/konseli. 
Kesadaran ini tercipta dari dirinya sendiri tanpa paksaan dan tekanan yang didasari rasa tanggungjawab yang tinggi dalam pengabdiannya memberikan layanan bimbingan konseling kepada peserta didiknya/konseli.

Berkelanjutan,

pengembangan keprofesionalan guru bimbingan konseling/ konselor hendaknya secara terus menerus harus dilakukan. Hal ini diperlukan mengingat adanya perkembangan zaman, perkembangan ilmu pengetahuan dan teknologi yang harus selalu diikuti bagi peningkatan layanan bimbingan konseling yang lebih baik. Tuntutan ini juga didasari fakta bahwa kebutuhan peserta didik selalu dinamis dan layanan bmbingan konseling juga selalu meningkat seiring makin banyaknya kesenjangan/persoalan hidup yang makin komplek.

Efektif dan efisien, guru bimbingan konseling/konselor hendaknya dalam melaksanakan pengembangan harus efektif yang berarti dapat mencapai hasil optimal yakni mampu meningkatkan

keprofesionalan semua kompetensi guru bimbingan konseling/konselor, penguasaan kompetensi yang makin kokoh sehingga pada akhirnya dapat memberikan layanan bimbingan konseling yang memandirikan peserta didik/konseli. Sedangkan efisien bermakna setiap pengembangan itu dilakukan dengan menggunakan sumberdaya seminimal mungkin dengan hasil yang optimal.

\section{RAGAM PROGRAM PENINGKATAN PROFESIONALISME GURU BIMBINGAN KONSELING/KONSELOR}

Peningkatan kompetensi guru Bimbingan konseling/Konselor dilaksanakan melalui berbagai program, pemerintah selalu membuat kebijakankebijakan dalam meningkatkan keprofesionalan guru bimbingan dan konseling/Konselor. Sehingga tidak ada alasan Guru Bimbingan Konseling/Konseloryang kesulitan mengembangkan keprofesional Konselornya. Dalam meningkatkan keprofesionalan Guru Bimbingan Konseling/Konselor melalui beberapa ragam metode, metode dalam bentuk pendidikan dan pelatihan (diklat) dan metode bukan diklat, antara lain seperti berikut ini.

\section{Pendidikan dan Pelatihan}

a. Inhouse training (IHT). Pelatihan dalam bentuk IHT adalah pelatihan yang dilaksanakan secara internal di KKG/MGBK, sekolah atau tempat lain yang ditetapkan untuk menyelenggarakan pelatihan. Strategi pembinaan melalui IHT dilakukan berdasarkan pemikiran bahwa sebagian kemampuan dalam meningkatkan kompetensi dan karir Guru Bimbingan Konseling/Konselor tidak harus dilakukan secara eksternal, tetapi dapat pula dilakukan oleh Guru Bimbingan Konseling/Konselor yang telah memiliki kompetensi kepada guru lain yang belum memiliki kompetensi. Seperti halnya guru yang telah menjadi instruktur kurikulum 2013 memberikan desiminasi kepada guru bimbingan konseling/konselor sejawat yang belum pernah mengikuti workshop kurikulum 2013.

b. Program magang. Program magang adalah pelatihan yang dilaksanakan di institusi/industri yang relevan dalam rangka meningkatkan kompetensi professional guru Bimbingan dan Konseling/Konselor. Program magang ini terutama diperuntukkan bagi Guru Bimbingan Konseling/Konseloryang berada di daerah terpencil, terluar, tertinggal sehingga bisa menimba ilmu keterampilan di sekolah kota, dan dapat dilakukan selama priode tertentu, misalnya, magang di sekolah yang terakreditasi A, sekolah rujukan dan yang sejenisnya. Program magang dipilih sebagai alternatif pembinaan dengan alasan bahwa keterampilan tertentu khususnya bagi Guru Bimbingan

Konseling/Konselormemerlukan pengalaman nyata dengan kompleksitas permasalahan peserta didik.

c. Kemitraan sekolah. Pelatihan melalui kemitraan sekolah dapat dilaksanakan bekerjasama dengan institusi pemerintah atau swasta dalam keahlian tertentu. Pelaksanaannya dapat dilakukan di sekolah atau di tempat mitra sekolah. Pembinaan melalui mitra sekolah diperlukan dengan alasan bahwa beberapa keunikan atau kelebihan yang dimiliki mitra dapat dimanfaatkan oleh Guru Bimbingan Konseling/Konseloryang mengikuti pelatihan untuk meningkatkan kompetensi profesionalnya.

d. Belajar jarak jauh. Pelatihan melalui belajar jarak jauh dapat dilaksanakan tanpa menghadirkan instruktur dan peserta pelatihan dalam satu tempat tertentu, melainkan dengan sistem pelatihan melalui internet dan sejenisnya. Pembinaan melalui belajar jarak jauh dilakukan dengan pertimbangan bahwa tidak semua guru terutama di daerah terpencil dapat 
mengikuti pelatihan di tempat-tempat pembinaan yang ditunjuk seperti di ibu kota kabupaten atau di propinsi.

e. Pelatihan berjenjang dan pelatihan khusus. Pelatihan jenis ini dilaksanakan di P4TK dan atau LPMP dan lembaga lain yang diberi wewenang, di mana program pelatihan disusun secara berjenjang mulai dari jenjang dasar, menengah, lanjut dan tinggi. Jenjang pelatihan disusun berdasarkan tingkat kesulitan dan jenis kompetensi. Pelatihan khusus (spesialisasi) disediakan berdasarkan kebutuhan khusus atau disebabkan adanya perkembangan baru dalam keilmuan tertentu.

f. Kursus singkat di LPTK atau lembaga pendidikan lainnya. Kursus singkat di LPTK atau lembaga pendidikan lainnya dimaksudkan untuk melatih meningkatkan kompetensi guru Bimbingan Konseling/Konselor dalam beberapa kemampuan seperti melakukan penelitian tindakan kelas, menyusun karya ilmiah, merencanakan, melaksanakan dan mengevaluasi pembelajaran, dan lain-lain sebagainya. Pembinaan internal oleh sekolah. Pembinaan internal ini dilaksanakan oleh kepala sekolah dan guruguru yang memiliki kewenangan membina, melalui rapat dinas, rotasi tugas mengajar, pemberian tugas-tugas internal tambahan, diskusi dengan rekan sejawat dan sejenisnya.

g. Pendidikan lanjut. Pembinaan profesi guru melalui pendidikan lanjut juga merupakan alternatif bagi pembinaan profesi guru di masa mendatang. Pengikutsertaan guru dalam pendidikan lanjut ini dapat berupa studi sarjana magister Bimbingan konseling (S2 BK) dilaksanakan dengan memberikan tugas/ijin belajar, baik di dalam maupun di luar negeri, bagi guru yang berprestasi. Pelaksanaan pendidikan lanjut ini akan menghasilkan guru-guru pembina yang dapat membantu guru-guru lain dalam upaya pengembangan profesi .

\section{Kegiatan Selain Pendidikan dan Pelatihan}

a. Diskusi ilmiah masalah pendidikan dan Konseling. Diskusi ini diselenggarakan secara berkala dengan topik sesuai dengan masalah yang di alami peserta didik di sekolah. Melalui diskusi berkala diharapkan para Guru Bimbingan Konseling/Konselordapat memecahkan masalah yang dihadapi peserta didik berkaitan dengan proses pembelajaran di sekolah dengan strategi-srtategi konseling ataupun masalah peningkatan kompetensi dan pengembangan karirnya.

b. Seminar. Pengikutsertaan Guru Bimbingan Konseling/Konselordi dalam kegiatan seminar dan pembinaan publikasi ilmiah juga dapat menjadi model pembinaan berkelanjutan profesi Guru Bimbingan Konseling/Konselordalam meningkatkan kompetensi guru Bimbingan dan Konseling/Konselor. Melalui kegiatan ini memberikan peluang kepada Guru Bimbingan Konseling/Konseloruntuk berinteraksi secara ilmiah dengan kolega seprofesinya berkaitan dengan hal-hal terkini dalam upaya peningkatan kualitas konseling dan kualitas pendidikan.

c. Workshop. Workshop dilakukan untuk menghasilkan produk yang bermanfaat bagi pembelajaran, peningkatan kompetensi maupun pengembangan karirnya. Workshop dapat dilakukan misalnya dalam kegiatan menyusun KTSP, analisis kurikulum 2013, pengembangan perangkat layanan, penulisan RPL, dan sebagainya.

d. Penelitian. Penelitian dapat dilakukan guru Bimbingan Konseling/Konselor dalam bentuk penelitian tindakan kelas (PTBK), penelitian eksperimen ataupun jenis yang lain dalam rangka peningkatan mutu pembelajaran.

e. Penulisan buku/bahan ajar. Bahan ajar yang ditulis guru dapat berbentuk diktat, buku pelajaran ataupun buku dalam bidang pendidikan.

f. Pembuatan media pembelajaran. Media pembelajaran yang dibuat guru dapat berbentuk alat peraga, alat praktikum sederhana, maupun bahan ajar elektronik (animasi pembelajaran),

h. Pembuatan karya inovatif Konseling. Karya inovatife konseling yang dibuat Guru Bimbingan Konseling/Konselordapat berupa karya Konseling On line yang bermanfaat untuk masyarakat dan atau pendidikan dan karya inovatif yang memiliki nilai estetika bermanfaat untuk dunia konseling yang diakui oleh masyarakat.

$\begin{array}{ccr}\text { Dari beberapa } & \text { macam } & \text { pengembangan } \\ \text { keprofesionalitas } & \text { Guru } & \text { Bimbingan }\end{array}$


Konseling/Konselordi zaman Now, memudahkan Guru Bimbingan Konseling/Konselormeng up gread kemampaun keilmuannya sehingga tidak ada lagi Guru Bimbingan Konseling/Konseloryang menjadi polisi sekolah, Guru Bimbingan Konseling/Konselordatang, absen, duduk, pulang.

\section{METODE/TEKNIK CONTINUING PROFESIONAL DEVELOPMENT (CPD) UNTUK PENGEMBANGAN PROFESIONAL GURU BK/KONSELOR}

Untuk mewujudkan guru yang profesional dan kompeten tidak cukup dengan mengikuti program sertifikasi dan menikmati tunjangan profesinya, ada dimensi yang harus dipenuhi agar profesionalismenya tetap terjaga, menjamin dan selalu meningkat sesuai dengan kebutuhan peserta didik serta tuntutan zaman yang berkembang antara lain dengan Pengembangan Keprofesian Berkelanjutan (Continuing Professionality Development/CPD) sebagaimana yang diatur dalam Peraturan Menteri Pendayagunaan Aparatur Negara dan Reformasi Birokrasi Nomor 16 Tahun 2009 tentang jabatan fungsional guru (Yasin, 2011).

Pengembangan Keprofesian Berkelanjutan (Continuing Professionality Development/CPD) guru salah satu metode pembinaan guru bimbingan konseling/konselor untuk mampu secara terus menerus memelihara, meningkatkan, dan mengembangkan keterampilan sesuai standar yang telah ditetapkan. Hal itu juga yang mampu meminimalisir kesenjangan antara kompetensi yang dimiliki guru bimbingan konseling dengan tuntutan keprofesionalan yang dipersyratkan. CPD merupakan suatu proses yang berkelanjutan untuk perkembangan individu dalam usaha untuk meningkatkan kompetensi secara utuh bagi seseorang profesional di ia tempat kerja. Hal ini hanya dapat dicapai dengan cara mengembangkan sepenuhnya ilmu pengetahuan, kompetensi, keterampilan dan pengalaman melalui aktivitas Pengembangan Keprofesian Berkelanjutan (Continuing Professionality Development/CPD.

Di antara prinsip-prinsip yang perlu untuk Pengembangan Keprofesian Berkelanjutan (Continuing Professionality Development/CPD seperti yang digariskan oleh RICS adalah sebagai berikut. (1) Pengembangan profesional merupakan kebutuhan akan individu. (2) Pengembangan profesional perlu secara berkelanjutan, serta tenaga profesional selalu proaktif untuk meningkatkan kompetensi diri. (3) CPD adalah urusan yang sifatnya pribadi atau hak tiap individu, sehingga mereka memahami apa yang terbaik dan yang diperlukan untuk peningatan keprofesionalan diri. (4) Tujuan pembelajaran juga harus jelas untuk membantu tujuan organisasi atau pelanggan dan sesuaidengan tujuan individu, (5) CPD harus dilihat sebagaikebutuhan seoarang profesional bukan dianggap sebagai satu pilihan (Nazim, 2007).

Profesional Association Research Network (PARN) di Amerika Serikat, memiliki beberapa strategi CPD yang dapat dilaksanakan yaitu: (1) CPD Secara mandiri, seorang guru bimbingan konseling/konselor mengikuti Program Pengembangan Profesional secara mandiri tanpa paksaan atau tekanan dari unit kerja. (2) CPD secara berkelompok, bentuk CPD ini merupakan pengembangan profesionalisme yang dilakukan oleh badan-badan profesional untuk meningkatkan pengetahuan sesuai dengan bidangnya. (3) CPD yang diwajibkan secara khusus. Profesional diwajibkan untuk menghadiri program CPD berdasarkan program pemerintah yang telah direncanakan oleh sebuah badan profesional sebagai syarat untuk memperbaharui keahlian profesional.

Berdasarkan beberapa model CPD yang telah ada, berikut metode yang dapat dilaksanakan dalam memperkuat bidang kompetensi profesional guru bimbingan konseling/konselor:

1. Pengubahan pola pikir bagi guru bimbingan konseling/konselor dalam pengembangan kompetensi profesionalnya.

2. Pengembangan/pemanfaatan fungsi organisasi profesi sebagai sarana pengembangan diri

3. Penguatan peran perguruan tinggi pencetak tenaga pendidik yang biasa disebut Lembaga Pendidikan tenaga Pendidikan (LPTK) dalam kegiatan penelitian serta kolaborasi antara dosen dengan guru serta kegiatan pengabdian masyarakat yang berorientasi pada pelatihan penguatan kompetensi guru bimbingan dan konseling

Melalui dukungan sistem, berkembangnya kompetensi konselor akan banyak tergantung pada kondisi sistem di mana konselor bertugas. Oleh karena itu, upaya peningkatan profesionalisme seyogianya berlangsung dalam sistem organisasi dan manajemen yang kondusif. Untuk hal ini perlu diupayakan agar organisasi dan lingkungan tertata sedemikian rupa sehingga menjadi suatu sistem dengan manajemen yang menunjang pengembangan profesionalisme guru. Manajemen dan sarana penunjang yang memadai sangat diperlukan untuk membentuk lingkungan kerja yang kondusif bagi pelaksanaan tugas guru Bimbingan Konseling/Konselor secara efektif.

\section{SIMPULAN}


Upaya pemerintah dalam mengembangkan keprofesionalan Guru Bimbingan Konseling/ Konselor sudah baik, melalui tahapan sertifikasi, pendidikan dan latihan profesi guru dan yang terakhir saat ini pemerintah mengembangkan Pendidikan profesi guru (PPG) semua itu merupakan metode untuk meningkatkan kompetensi dan keprofesionalan guru Bimbingan dan Konseling/Konselor. Peningkatan kompetensi guru Bimbingan konseling/Konselor dilaksanakan melalui berbagai metode, pemerintah selalu membuat kebijakan-kebijakan dalam meningkatkan keprofesionalan guru Bimbingan dan Konseling/Konselor. Sehingga tidak ada lagi alasan Guru Bimbingan Konseling/Konselor yang kesulitan mengembangkan keprofesional Konselornya.

Untuk mewujudkan guru bimbingan konseling/konselor yang profesional dan kompeten tidak cukup hanya dengan mengikuti program PLPG/PPG, pemerintah harus memiliki program lanjutan setelah guru Bimbingan konseling/Konselor memiliki sertifikat profesional untuk mempertahankan dan meng upgread keilmuan sesuai perkembangan zaman, ada aturan yang harus dipenuhi agar profesionalismenya tetap terjaga, menjamin dan selalu meningkat sesuai dengan kebutuhan dan tuntutan yang berkembang antara lain dengan Pengembangan Keprofesian Berkelanjutan (Continuing Professionality Development/CPD). Pemerintah melalui P4TK atau melalui kerjasama dengan organisasi profesi, MGBK bisa mengoptimalkan pengembangan keprofesian berkelanjutan melalui dukungan sistem, perkembangan kompetensi konselor akan banyak tergantung pada kondisi sistem di mana konselor bertugas. Oleh sebab itu, upaya peningkatan profesionalisme seyogianya berlangsung dalam sistem organisasi dan manajemen yang kondusif.

\section{KEPUSTAKAAN}

Depdiknas. 2005. Pelatihan Terintegrasi Berbasis Kompetensi Guru BK (PTBK-Guru BK), Jakarta: Direktorat PLP Ditjen Dikdasmen.

Depdiknas. 2008. Penataan Pendidikan Profesional Konselor dan Layanan Bimbingan dan Konseling dalam Jalur Pendidikan Formal, Jakarta

Depdikbud. 2007. Rambu-rambu Pelaksanaan Bimbingan dan Konseling Pada Jalur pendidikan Formal, Jakarta:Dirjen PMPTK

Gysbers, Norman C. \& Henderson, P.2006. Developing and Managing Your Shool Guidance and Counseling Program,
Alexandria: American Counseling Asocation.

Kemendiknas. Nomor 27 Tahun 2008. Tentang Standar Kualifikasi Akademik dan Kompetensi Konselor, Jakarta:

Nazim, M. 2007. Keperluan ProgramPembangunan Profesional (CPD) Terhadap Profesional Juru Ukur di Malaysia. Universitas Teknologi Malaysia

Permendikbud. Nomor 111 tahun 2014. tentang Bimbingan dan Konseling pada pendidikan Dasar dan Menengah,

P4TK. 2017. Pengembangan Keprofesian Berkelanjutan Bimbingan dan Konseling, Jakarta:Dirjen GTK

Kartadinata,Sunarya. 2010. Isu-isu Pendidikan: antara Harapan dan Kenyataan. Bandung:UPI Press

Undang Undang RI Nomor 20 tahun 2003. tentang Sisdiknas, Jakarta: Depdiknas.

Undang Undang RI Nomor 14 tahun 2005. tentang Guru dan Dosen. Jakarta: Depdiknas.

Uno, H.B. 2010. Profesi Kependidikan, Jakarta: PT Bumi Aksara.

Widada. 2013. Profesi Bimbingan dan Konseling, Malang: FIP Univesitas Negeri Malang

www.strath.ac.uk. 2006. Continuing Professional Development, (Online), (www.cll.strac.ac.uk/CPD.html.14.12.2006), diakses 28 Sepetmber 2018.

Yasin, A. 2011. Paradigma Baru Pengembangan Profesi Guru. (Online), (http://mebermutu.org/media2.php?module= detailknowledge\&id=35), diakses 28 Sepetember 2018 